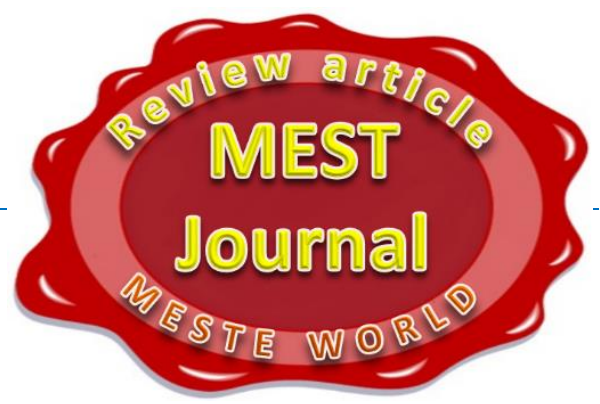

\title{
TRANSFORMATION OF INSTITUTION OF EMPLOYMENT AS AN ADAPTATION OF THE LABOR MARKET
}

\section{Victoriia Blyzniuk}

Institute for economics and forecasting NAS of Ukraine, Kyiv, Ukraine

\section{Larisa Guk}

Institute for economics and forecasting NAS of Ukraine, Kyiv, Ukraine

\section{(C) MESTE NGO}

JEL Classification: E24, J21, J22, J23, J44

\begin{abstract}
This paper deals with the development of the labor market under the economic uncertainty. Analysis of the formation of flexible forms of employment in the country revealed that on their basis the adaptation strategies of labor market transition are formed. Proved, that the growth of employment in Ukraine is largely due to deformalization of employment. This makes it possible to reduce the likelihood of unemployment and maintain qualification skills of employees, but the state budget would receives less tax revenues, which increases the risk of budget deficits.

It is determined, that the distribution of new schemes using temporary involved (borrowing) work normally carried out within the framework of outsourcing, outstaffing and staff leasing under the terms of a civil labor contract. Labor legislation of Ukraine does not regulate legal relations connected with dealerships in hiring personnel through a civil contract and this eliminates employee rights, guarantees and compensations stipulated by labor legislation. It is proved that there is an urgent need for legislative regulation of the use of flexible forms of employment.

It is proved that the development of modern information and communication technologies and increased demand for new services specific to the information economy, leads to a new direction of development of remote employment - freelance. This paper investigates the dynamics of changes in the occupational structure of freelancers in Ukraine, which allowed us to identify major trends and key labor market trends in the field of remote employment. We also identified the benefits of non-standard flexible forms of employment and the problems they generate in the field of labor relations.
\end{abstract}

Keywords: labor market, employment, nonstandard employment, employment adjustment, labor supply

Address of the corresponding author: Victoriia Blyzniuk 拝”/ v_blizniuk@mail.ru

\section{INTRODUCTION}

Recently an evident trend towards flexibilization of labor market reveals itself increasingly in developed countries. Objective basis for this 
phenomenon are the new achievements of scientific and technological progress, the individualization of the labor process. Emerging trends of economic development come into conflict with strict regulation of working conditions bring to life new forms of work organization and remuneration, non-standard forms of labor market functioning. Individual terms of recruiting and the use of employees in the workplace are created. The formation of a flexible labor market can go in different directions and take various forms. Among them we can mark out nonstandard modes using full-time employment; non-standard forms of employment; increased flexibility in matters of hiring, firing, rotation.

\section{BRIEF LITERATURE OVERVIEW}

The issue of labor market flexibility and the use of non-standard forms of employment are the focus of Ukrainian scientists: S. Bandur, L. Beztilesna, O. Grishnova, A. Kolot, E. Libanova, L. Lisogor, Y. Marshavin, I. Motorna, I. Petrova et al.

The study of specific mechanisms of adaptation of the labor market, and especially the flexible nonstandard forms of employment are the main areas of research of western economists and sociologists. According to the American sociologist A.Kalleberh, the standard hierarchical organization of labor relations rather a historical anomaly, while various forms of non-standard employment - general rule (Kalleberg, 2000). Casey B. writes about flexibility of the labor market (Casey, 1991). Dutch economists T. Wilthagen, (2004) and F. Tros, (2004) developed the concept of a secure flexibility (flexicurity), devoted to analyzing the impact of flexible labor market institutions on its operation (Wilthagen \& Tros, 2004). However, it is safe to emphasize that the problem of the use of flexible forms of employment in an unstable Ukrainian labor market is still understudied.

\section{PURPOSE}

Very important today is solving scientific task to assess the advantages and disadvantages of the use of flexible forms of employment in the Ukrainian labor market and to identify opportunities to use them for the labor market of Ukraine. These questions our dedicated article is devoted to.

\section{RESULTS}

Natural population increase remains negative in Ukraine therefore the demographic process predetermines a labor shortage. Because of the demographic challenge Ukraine has to recruit labor migrants. But migration policy for the purpose of migrants' integration into Ukrainian society can lead to deformation in the society. Therefore wide application of partnership between government and private sectors is reasonable. The partnership has established a reputation in various countries.

State and business structures (including TNC), international agencies forco-operationand development, public organizations (such as Diasporas and religion ones), donor organizations may operate as agents and interested parties.

Indicators of labor supply on the labor market are defined by economically active population amount. Economically active (15-70 years-old) population made up 22.01 million at the end of 2012. That is $16 \%$ less than it was in 2000 but relative ratio such as population economic activity level has increased 1.4 percentage point. The highest level of economic activity has been observed traditionally for $35-49$ age group (for men and women as well). Rise in economic activity level of the group is provided with rise in level of employment.

Levels of employment in Ukraine are higher than average ones in European Union countries. In 2012 level of employment in Ukraine reached $59.7 \%$ of economically active (15-70 years old) population (State Statistics Service of Ukraine, 2013). In 27 EU countries it averaged $51.7 \%$ of population aged 15 and over (Eurostat, 2013). Levels of employment in Ukraine have been constantly grown from $55.8 \%$ of economically active population in 2000 to $59.7 \%$ in 2012 . Youth employment becomes a problem of great importance. Youth reach the highest level of employment at age 30-34 when problem of the first job has alreadybeen solved and person has already reached defined professional level. Level of employment for aged 25-29 group is in essentially less. For the youngest (aged 15-19) level of employment is minimal that can be considered as a positive phenomenon, since at this age is more important to study and learned a trade.In the future it willraise a competitive abilityof 
young people. Comparing the levels of employment in different types of population centers, we can see that village youth enters the labor market earlier than the urban one but later on itprefers passive behavior strategy on the market or migration to towns, where there are more possibilities for getting a job (State Statistics Service of Ukraine, 2013).

Over a period of time previous to economic and financial crisis 2008-2009 there was some economic recovery accompanied by Ukrainian labor market stabilization and structural changes. But outstanding feature of that stage of development was low quality of employment. Employability (as a chance to get a job) was reducing constantly while economic activity was increasing. Interaction of these trends caused some negative self-strengthening economic processes on the labor market, in the economy and society. Growth of unemployment in Ukraine took place not only for account of noncompetitive individuals but for account of high educated and qualified professionals. So national labor market before the world economic and financial crisis was characterized by following features: low unemployment rate that was accounted for by inelasticity of employment with respect to GDP change, presence of structural disparities between labor supply and demand, excess of wage increase rates over labor productivity growth rates. Crisis aggravated the existing problems and demonstrated unsystematic character of employment policy in Ukraine. So far, as amount of officially registered unemployed is directly correlated to the financial position of the state, some administrative measures were used during the last crisis to avoid massive lay off sand applications for unemployment status. Employment policy was primarily protective one and supported social stability, assisting in job placement for uncompetitive workers and fixing job quotas for them. That assists in unemployment level reduction.

Beginning of crisis did not lead to countrywide mass unemployment, and chronic jobless was avoided. Relative employment stability and reasonable level of registered unemployment were the main achievements of state authority, when it was opposed to consequences of a crisis for Ukrainian labor market.
Number of citizens which lost their work and became the job seekers reached peak in JanuaryFebruary 2009 but in second half-year signs of labor market stabilization were outlined. Unemployment level came down and at a later date it became lower than the indicator of EU countries, where unemployment sluggish growth has still been occurred. This might be a limiting factor for the following labor migration from Ukraine. The main problem in Ukraine is not an unemployment level itself but growth of the part of people who have sought for a job for 12 months and more. That means stagnancy intensification.

Job vacancies arose up to 2009 primarily at the expense of dismissal of blue-collar workers. Then a gap between number of blue and white collar redundant workers gradually narrowed. Crisis did not cause liquidation of jobs for unskilled employee. Dismissal level for jobs which did not need a special training remained stable. Labor demand traditionally was formed at the expense of manual workers but during crisis a demand for office employee increased (Figure 1).

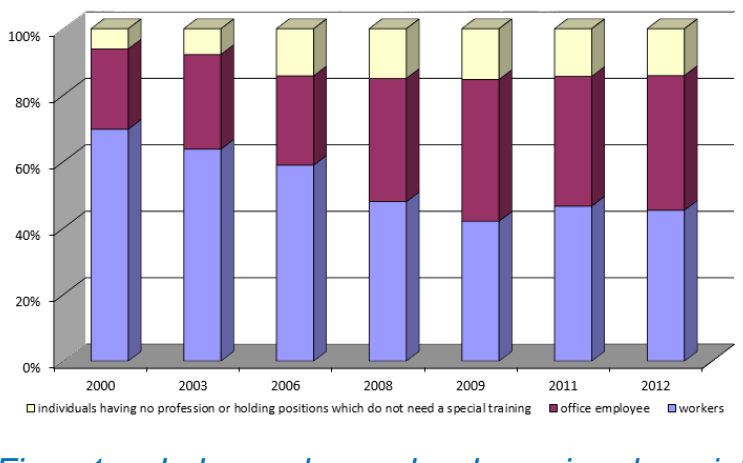

Fig 1. Labor demand dynamic by job categories(Source: official website of the State Statistics Service of Ukraine: http://www.ukrstat.gov.ua/)

The employment structure formed in Ukrainian economy during transformation period is not optimal. It still does not meet requirement of postindustrial society but describes labor deindustrialization process. When market-style reforms began, the growth of employment in services sector was expected. But as for Ukrainian labor market the "service" mainly means trade and also hotel and restaurant business. Reduction in industrial employment could be considered as a positive sign if employment in information and communication field were increased. Regretfully such trend in Ukraine is absent. 
MEST Journal Vol. 3 No. 1 pp. 68-80

It is practically impossible to achieve balance between demand and supply of labor force in the modern job market only with market mechanisms (dynamics of the labor cost), the state implements a specific set of measures to ensure such a balance, which is an employment policy aimed at: ensuring the growth of population employment, stimulating employment of citizens who are not competitive in the labor market, self-employment of the population and job creation by small businesses, strengthening social protection against unemployment and ensuring reduction in the number of unemployed; increasing state regulation of employment.

Today, within the social and labor sphere there are a number of problems that need to be solved. First is the low level of wages, which leads to poverty of the working people (even minimum wage in Ukraine is 3 times lower than in Lithuania, and 20 times - than in the UK), there are back pays and other problems. Especially dangerous is the gap between actually implemented and formally set rules and regulations in the field of social and labor relations. Recently hasty and random and therefore inefficient decision-making in labor compensation only hampers further progress in complex addressing social problems.

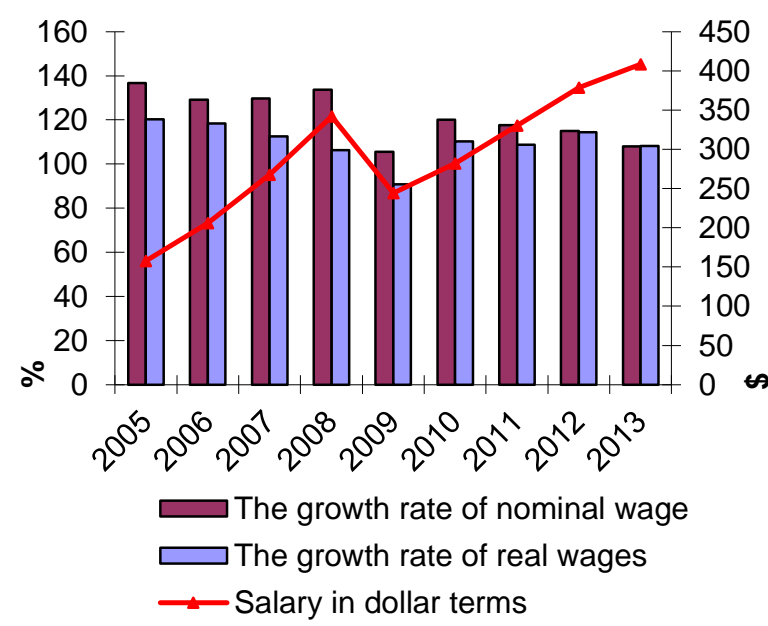

Figure 2. Dynamics of wages in the pre-crisis, crisis and post-crisis periods (Source: calculated by the authors according to the State Statistics Committee of Ukraine [electronic resource] Available at: http://www.ukrstat.gov.ual and the National Bank of Ukraine [electronic resource] Available at: http://www.bank. gov.ua /)

The consequences of the recent crisis became the decrease in real wages in almost all industries, understatement of the cost of labor force and unjustified differentiation of wages between certain groups of employees. Analysis indicates that real wages and salary in dollars regained the pre-crisis level only in 2012 (Fig. 2).

The highest salary for an extended period is kept in the same activities. According to results of 2011 these are financial activity (5340 grn), transport (particularly airlines - 8742 grn), metallurgy and manufacture of fabricated metal products (exportoriented industries, $3539 \mathrm{grn}$ ) and mining industry (4370 grn).

We can predict that the negative situation with deformities in remuneration of labor is not typical for all sectors of the industry. It will remain primarily in the public sector of the Ukrainian economy, where the impact of the crisis was particularly clear.

The problem of remuneration of labor in the public sector is one of the most painful one in the economic policy of Ukraine. For the majority of public sectors the composition and level of the personnel, the availability of highly qualified professionals, as well as an opportunity to attract young professionals are of particular importance. However, conditions of labor compensation clearly do not meet this task.

Given that the public sector employs about $34 \%$ of all staff employed in the economy of Ukraine, the issue concerning optimization of their remuneration is undoubtedly very important (the concept of "public sector employees" include all employees whose salary is funded from the budget sources of different levels).

It should also be noted that mental, scientific, and cultural fundamentals of the society are exactly in the public sector, that the most educated human potential, the source of intellectual resources are concentrated there that we are losing each year primarily due to material demotivation (through internal migration to the commercial sector and external one - to countries with a higher standard of life). Limitation in remuneration of labor of employees of public sectors is unjustified not only in terms of social priorities but does not have an objective basis, as the skill level of public sector employees in general exceeds the qualification level of the other sectors of the economy. Although the mobility of employees in the sector is low, in recent years a lot of qualified professionals 
(majority of public sector employees are in education, healthcare, science and most of these areas experienced the outflow) were lost.

Statistics show a continuous underpayment of employees of public sectors that does not encourage their recruitment with perspective, qualified specialists, and leads to higher concentrations of less productive employees. Despite the relatively high growth rate of the nominal wage in this area that took place in 20012007, the level of payment remained consistently low here. For example, the average salary for the first half of 2012 in healthcare accounted for $62.1 \%$ of wages in industry and in education $73.6 \%$ (given that before 2001 the rule was applied in Ukrainian legislation, according to which the average salary of academic teaching staff of the higher educational institution had to be at a level no lower than twice the average wage in the industry). Thus the variation in the range gap for certain categories of employees were quite

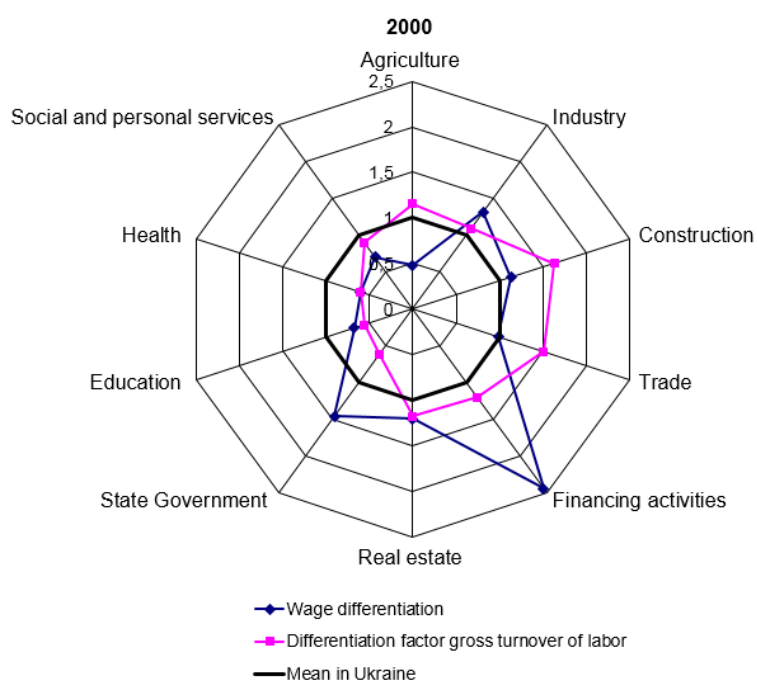

substantial. It is clear that in the present situation of budget savings it is incorrect to suggest the increase in remuneration of labor. However, even under these conditions it makes sense to highlight the problem of determining the fair labor compensation. Today it is possible to implement structural reform of remuneration of the labor in the public sector without reducing the financing that will preserve the high level of qualification and ensure the principle of justness in labor compensation.

Wages are the main determinant of the sectoral mobility of employees. Thus, Figure 3. graphically shows differentiation (deviation from the average in Ukraine) in the ratio of employee turnover and wages by sectors in 2000 and 2012 respectively. It can be concluded that for those sectors where wages are significantly behind the average values for Ukraine, rates of mobility are significantly higher.

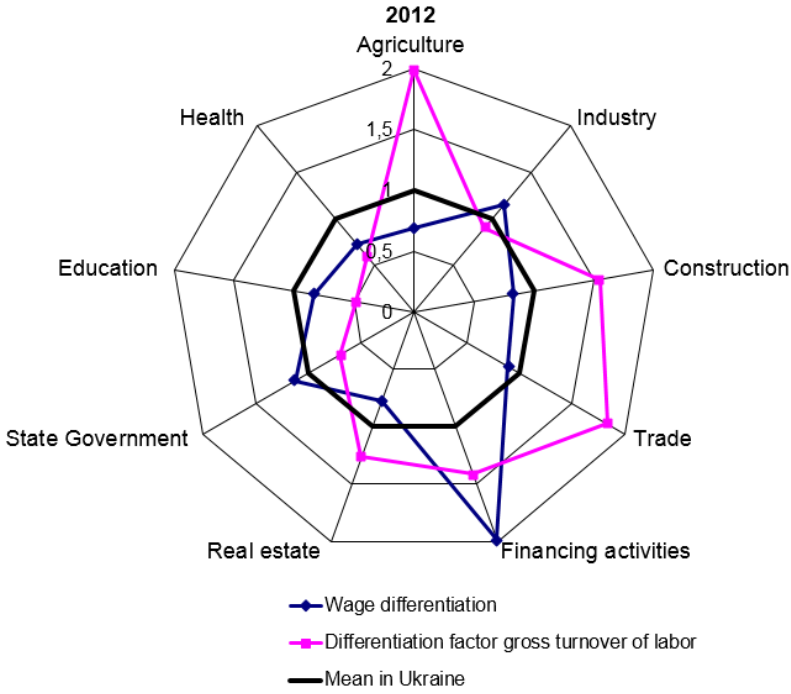

Fig.3: Sectorial differentiation of wages and labor mobility in Ukraine's labor market in 2000 and 2012

This situation exists primarily for agriculture, where differentiation factor by mobility is twice higher than the average for Ukraine, construction and trade sectors, where wages, which stand behind the averages in Ukraine, cause movement of workers. For financing activities, industry, public administration there is a situation at which wages are higher than average and therefore the human potential is more stable. Comparison of the differentiation by mobility and wages shows that, despite the understated indicators of labor compensation in education and healthcare, people employed in these areas are characterized by low mobility, which can be explained by the accumulation of specific human capital, which cannot be used in other areas, and the presence of certain social guarantees to employees, which positively affects the human potential of these sectors. For such types of economic activities like trade, construction the role of specific human capital becomes insignificant and the change of work brings out the individual much more than the return from a 
specific experience - experience in one area of employment.

The dynamics of gender differences in remuneration of labor in Ukraine is fairly stable phenomenon. Thus, the average economic ratio of wages of women and men over the last three years (2010-2012) amounted to $77.8 \%, 74.9 \%$, and $77.6 \%$, respectively. But the gender gap in terms of economic activity has some differences. For example, in agriculture and forestry the wage of the average woman according to data of 2012 is about $89.3 \%$ of men's wages, in education $91 \%$, in healthcare $-90.5 \%$ (Figure 4 ).

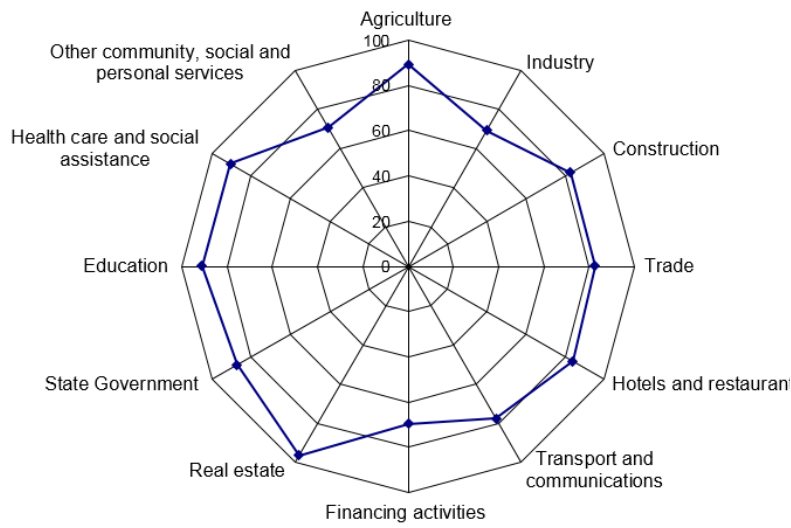

Figure 4: Ratio of average wages of women and men in economic activities in Ukraine in 2012

At the same time in the financial sector this ratio is less than $69.6 \%$, and in the sector of public, social and personal services $-70.8 \%$. What can explain the differences in remuneration of labor between men and women in Ukraine? Issues of gender differences in payment ever belonged to the circle of interest of researchers of women status in economic activities. For example, Brainerd E. (2000) finds that the transition to a free-market economy had negative impact on the status of women in the labor market in Russia and the former Soviet Union countries. Some of reasons of the sharp increase in the wage gap between women and men from 20 percentage points in the early 90 s to $30-35$ percentage points in the mid-90s, which is the worst among CentralEast European countries he sees in inequality of the accumulated human capital, levels of labor activity and employment structure as well as in the presence of discriminatory behavior of employers in the market. These findings correlate with the data presented in the Newell, Reilly (2001).
In the economic literature on the analysis of gender wage differentials there are three main reasons for differences in wages between women and men distinguished more often (Blau, F. and L. Kahn (2006); Jurajda, Š. (2005); Pastore F, \& Vereshagina A. (2007)). First of all, the gender wage gap is explained by differences in the amount of accumulated human capital, both general and specific. Another reason, which may be distinguished, is the concentration of employed men and women in different sectors of the economy, jobs and occupations, and the third one indicates the existence of discrimination against women in the labor market.

Mechanism of regulation of the labor market of Ukraine should combine financial, structural and investment, social and economic, organizational and managerial components in the overall system of economic management and be implemented in the context of regional policy of economic reforms. Fundamental principle of economic regulation of the labor market should be the real cost of labor and effective employment of population, which in our case involves the activation of the process of the release of excessive labor force, the formation of the mobile labor pool, and the legalization of concealed unemployment.

An important factor of active and effective adaptation strategies for transitional societies is a reliance on the flexible employment models to support or replace the basic, standard employment. Ukrainian labor market, as the labor markets of other countries, is liable to significant changes under conditions of globalization. Implementation of reforms (in order to soften a crisis impact on the labor market) led to spreading of nonstandard employment. Labor force which is able to adapt immediately to changeable circumstances in the labor market was formed.

Globalization sets up new claims to labor force concerning its qualification and general educational attainment as far as "human factor" became a key element of new model of postindustrial development (Petrova, Blyzniuk \& Kulikov, 2009). Standard employment gives place to atypical kinds of employment. Their spreading has objective social and economic grounds. Demand for nonstandard employment including part-time, irregular, distant or even informal ones is formed not only by employers but by certain 
social groups: women, students, pensioners, freelancers and so on.

Today in Ukraine job growth of Ukrainian population takes place in a great measure at the expense of informal (shadow) sector of economy. Widening of informal economy during 2010-2012 enabled partly to absorb employee fired from formal sector, as a result of financial and economic crisis. In 2012 number employed in informal sector came to 4.7 million or $22.9 \%$ of employed population $15-70$ age group. Expansion of the service sector as a result of Ukrainian economy transformations effected informal employment structure (Figure 5).

During 2007-2012the maximal growth was observed in construction (3.8 percentage point) and trade (1.0 p.p.) per year. Agriculture is the main branch among other informal economic activities but there was observed a reduction in employment by 5.7 percentage point. Taking into consideration that $22.9 \%$ of employed population got job in informal sector in 2012, we can draw a conclusion that crisis intensified trend for deformalization of the employment structure. On the one hand, it is good that employed workers have not become unemployed or economically inactive. They maintain their work skills and habits. On the other hand, the State budget receives less tax revenue and a budget deficit is possible.

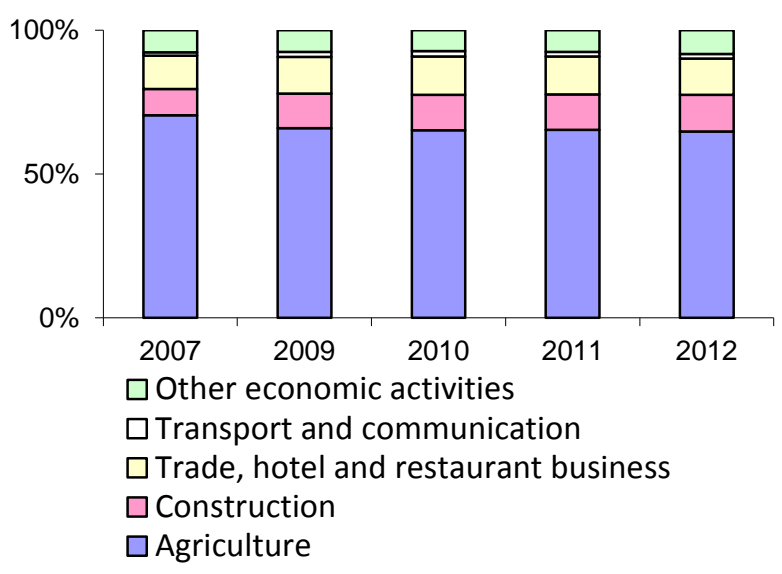

Fig.5: Informal employment structure in Ukraine (Source: official website of the State Statistics Service of Ukraine: http://www.ukrstat.gov.ua/)

Besides technological factors there is a considerable role of demand for the new service that is inherent in information economy. Employers need specialists of information technology sphere. Importance of professionals who involved in work with information and have creative personal abilities grows rapidly. Also grows as hare of the jobs connected with information processing, relative to ones where material values are produced. However intention to reduce staff costs leads to transference of work activity outside office and widely-spread creation of flexible (virtual) workplaces. According to the researchers $\mathrm{O}$. Pavuk and N. Moldenhower, as a result of the introduction of new technologies, correlation between the number of employees and growth of the industry is becoming less pronounced. It is the key manifestation of virtualization of economy (Pavuk \& Moldenhower, 2013).

Virtual working environment of flexible employment provides for application of information and communication technologies (ICT). It means working through the information networks, working from home and special centers distant from the main company office (Motorna, 2008).We analyzed data from the cite freelance.com.ua which is specialized in working home employment. Information concerning changes in freelancers ' professional structure in Ukraine made it possible to reveal main trends of labor market development in distant employment sphere (Figure 6).

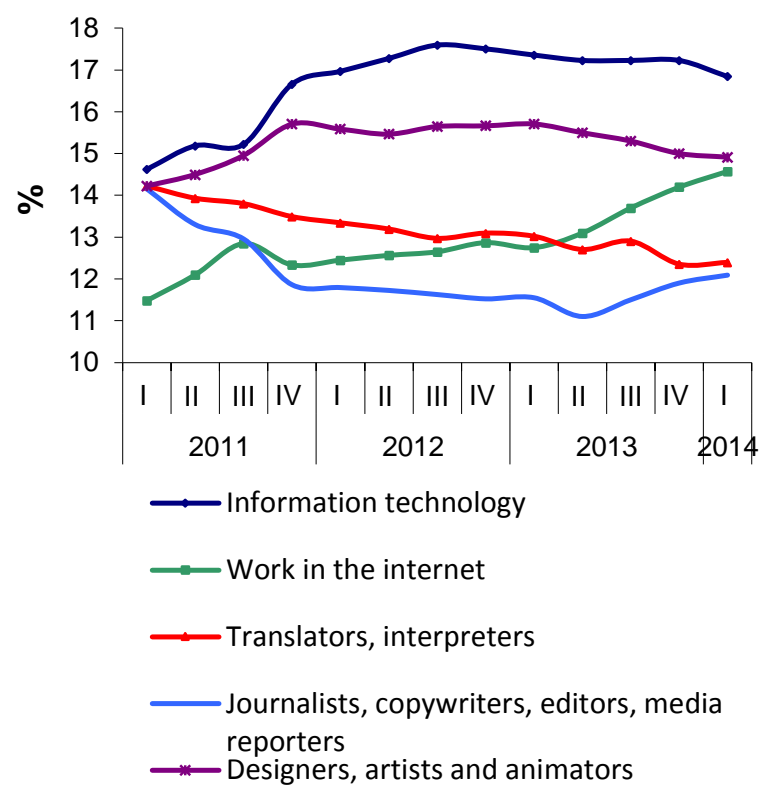

Fig.6: Proportion of freelancers by profession in 2011 - 2014 (Source: Compiled by the author L.Guk according to cite freelance.com.ua) 
Besides technological factors, a significant part in employment structural change plays demand for a new service typical for information economy. During 2011-2014 information technology market demonstrated dynamic development. Number of freelancers at that period increased by 4.8 times, share of employed in this sphere was the greatest (16.8\% by 2014$)$. Employment related to work in the internet also developed dynamically. Share of freelancers in that sector increased by 3.1 percentage point. Designers, artists and animators form considerable part of freelancers. Since 2011 it increased by 0.7 p.p. and reached $14 \%$. For that period apart of copywriters, editors, media reporters and translators fell but total demand for service of working home employee has grown impressively. According to the data of citefreelance.com.ua, number of projects per one freelancer permanently increases (Figure 7).

Official statistics claims that average labor income of a freelancer has nothing in common with average wage in the country and for majority of freelancers it is only an additional income to earnings at the place of primary employment. According to findings of a public opinion polls, $25 \%$ of respondents earn less than $100 \$$ per month. Only $7 \%$ succeed in earning $1000 \$$ per month (Labor market analysis, 2010). Earnings of a freelancer may be striking different by the month but it is impossible to control them because of absence of relevant statistics. Growth in number of distant employees in Ukraine is expected, because remuneration of Ukrainian freelancers is several times less than Russian or West European ones, and quality of their work can match international standards.

In Ukrainian labor market begin to expand new mechanisms for arranging temporary, borrowed labor force usually in the form of outsourcing, outstaffing, and employee leasing. Outsourcing means giving the responsibility for running a particular business-process or production function to another company (companyoutsourcer) specialized in appropriate sphere of activity. For example, cleaning, catering, legal, account, IT, call-centre service, and so on. Service and support are usually occasional or episodical and are limited by start and finish. To outsourcer usually are transferred the function of professional support for trouble-free operation of some systems or infrastructures on basis of agreement (as minimum for one year).

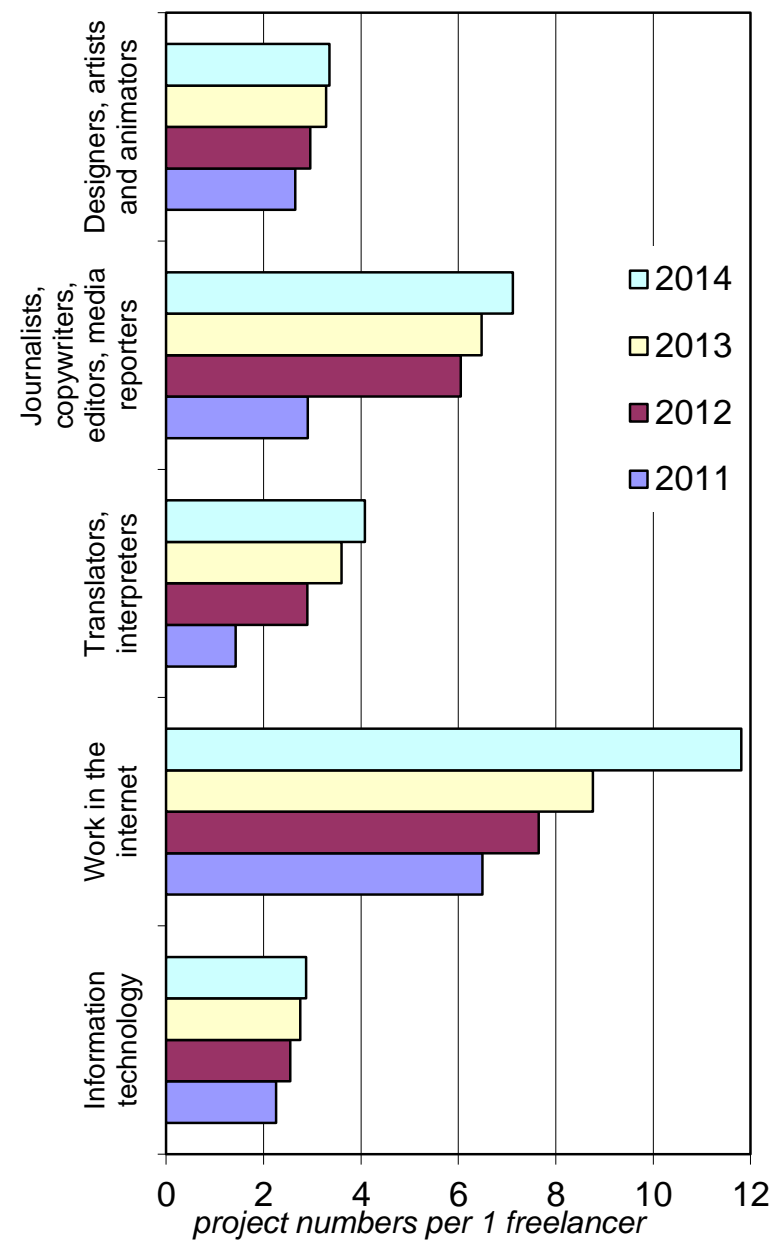

Fig.7: Project number per 1 freelancer in 2011 - 2014. (Source: Compiled by the author L.Guk according to the data of cite freelance.com.ua)

Outstaffing occurs when company for a time of certain work, enlists non-staff freelancers who have corresponding knowledge, skills, and experience. In contrast with outsourcing, an outstaffing provides for transfer of concrete workers. They are taken on the staff of companyprovider (professional employer organization, staffing company) working in actual fact for the company-customer. But in practice by outstaffing often is understood a removal an employee out customer's staff and putting him on the provider's staff. At the same time an employee continues with his job at previous workplace but employer liability is laid on the provider.

Ukrainian labor legislation does not regulate the legal relationship connected with intermediation 
under employment. Setting up an employment contract provides for reciprocal rights and duties between employee and provider but not between employee and a customer. In case of outstaffing a civil law contract is concluded and that deprives an employee of rights, guaranties, and compensations provided by labor legislation.

Staff leasing is a management technique that enables to supply company-provider's business process with necessary labor force enjoying service of lessor (professional employer organization, staffing company).When leasing a staff, customer does not conclude a labor contract with an employee and also may refuse his service any time if it is provided by agreement between lessor and the customer. Fundamental difference between staff leasing and outstaffing is following. Under outstaffing a termination of labor agreement between employee and a customer entails termination a contract between customer and provider which has the employee on its staff. Under the staff leasing labor relations between employee and a lessor remain valid.

Rapid growth of borrowed labor application indicates that such labor is productive. Its advantages consist in rise of labor market flexibility, lowering a stagnant unemployment, creation temporary or (sometimes) long-term jobs. The professionals not being on staff are involved into important high-skill job (advertising and design, computer and technical backup, financial management and audit, consulting, projecting, and so on). Applying new forms of labor management the employers can reduce product cost; reduce training budget and cost of motivation. They also can avoid prolonged and expensive procedures related to hiring and dismissal; maintain core workers employment for account of casual ones. It is possible to take off the staff non-core services delegating them to company-agent, thus reducing a tax burden and making own company more attractive to the investors.

As S. Hauseman affirmed, demand for temporary workers depends on company size, location (distance from a big city), seasonality of production, existence of trade unions, and structure of incentives, if social package exists or not (Houseman, 2001). Temporary employment probability is higher at the big companies, in the big cities, for seasonal jobs, under absence of unions, etc.

There are a lot of irregular employment patterns watched on the labor markets of different countries. As for Ukrainian one it is possible to single out two main subtypes of irregular employment:

1) employment for a specified period (seasonal, temporary);

2) casual employment.

Employment for a specified period (seasonal, temporary) conforms to labor relation, meant for preconcerted period of time (including one that is long enough, 2-5 years), and it can be prolonged or recommenced after termination. Irregular employment might not come within the purview of labor legislation and may be regulated with civil standards. That is an employment for performance of a certain scope of work. Employment on the ground of oral arrangement is an extremely unstable employment basis, since in this case the employee finds himself devoid of any formal guaranties for continuity of employment. The most instable employment pattern is so called casual employment which means performance of individual works occasionally.

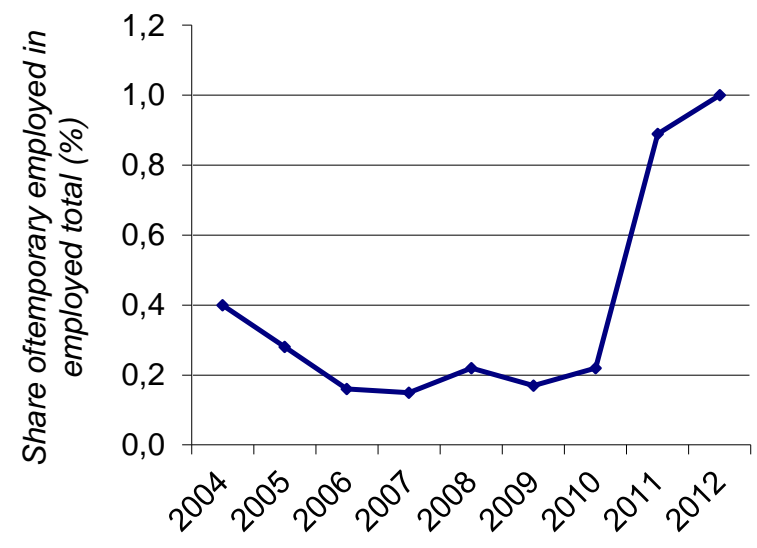

Fig.8: Dynamic of temporary employment level in Ukraine, 2004 - 2012. (Source: Compiled by the author L.Guk)

Distinguishing features of casual labor relations are their extremely short-term type under absence, as a rule, any formal arrangement. Range of such activities is enough wide: occasional repair, cleaning, nursing, baby-sitting, translation and some. 
Number of temporary employed in Ukraine exceeded 865.17 thousand. They have $4.3 \%$ share of employed total that was a bit less than average for OECD countries. Like OCED, in Ukraine the scope of temporary employment grew rapidly from $0.4 \%$ in 2004 to $4.6 \%$ in 2012 i.e. 4.2 percent point increase (Figure 8).

Growth of temporary employment was uneven. Considerable increase was seen in 2011. That rise, in our opinion, was caused by methodological changes in statistical procedures for measurement of the temporary employment. Since 2011 the Ukrainian State Committee on Statistics begins to use variational list of temporary employment patterns. Sample survey statistics of population concerning economical activity during 2011 , enables to separate out the temporary employment and casual one. Temporary employment level was equal to $3.4 \%$ and casual one $-0.9 \%$ of employed total.
Comparing these data with the showings for the former period, we can see that temporary employment level was considerably underestimated. Provided that part of employed workers having temporary contracts (particularly long-term ones) could identify themselves as permanent, they could underestimate actual irregularity of their employment.

Temporary employment is widely-spread among all social-demographic groups of population, so it makes this type of employment very mixed. But diffusion level is different. In developed countries, as it shown in the Figure 9, share of temporary employed among women is much bigger than among men. In Japan and Finland women accounts for more than $60 \%$ of temporary employed, in most countries - about a half. Only in Turkey, Russia, Estonia and Ukraine the situation is opposite, and risk of temporary employment is higher for the men.

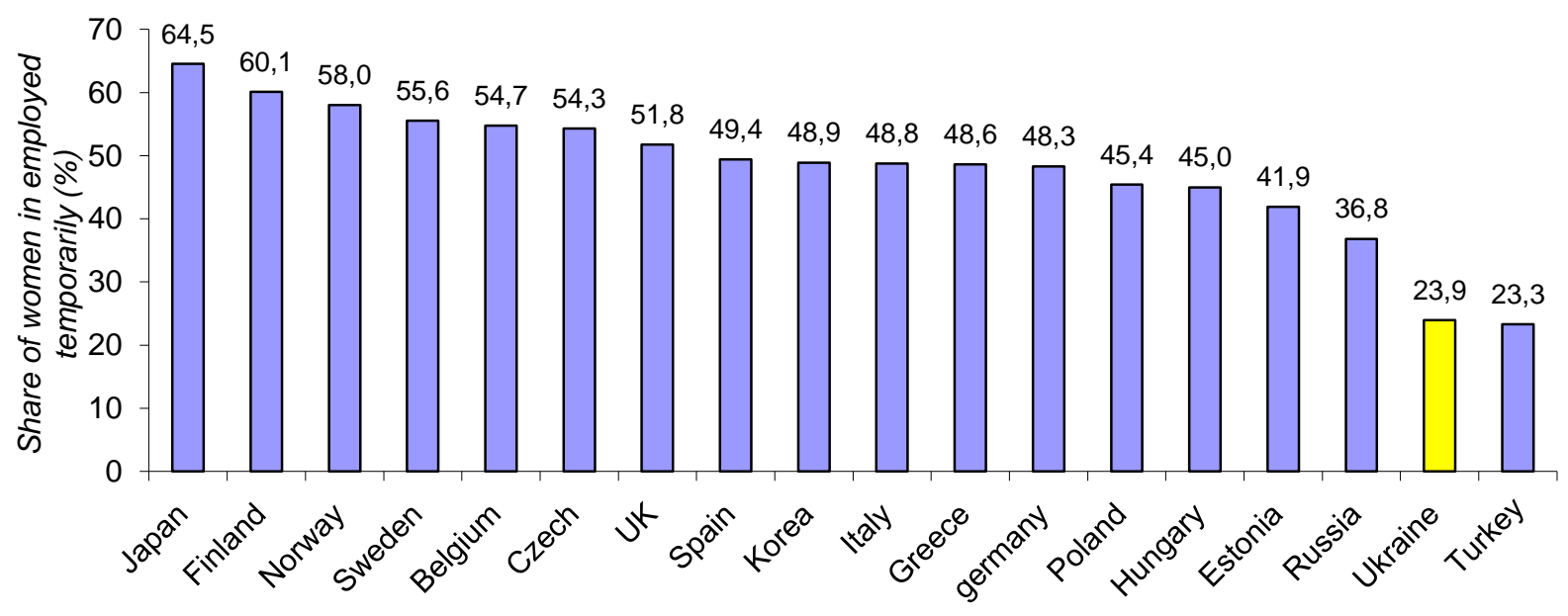

Fig.9: Share of women in temporary employed total, 2011 (Source: Compiled by the author V. Blyznyuk)

In Ukraine, unlike the majority of other countries, there is much more probability for men to be employed on irregular basis, than for women. In 2011, temporary employment level for men amounts to $6.3 \%$ (2.1\% for women). Men made $76.1 \%$ of temporary employed total, when women - only $23.9 \%$, so temporary employment is inherent in men population much more than in women one.

Temporary employment simplifies for employers a dismissal procedure of workers. Since compensation for dismissal of such employee is minimal, we find conceivable that this pattern of nonstandard employment will cover the least productive workers. Investments in their education and professional training are the lowest, and there is enough supply of such workforce on the market.

Application of flexible employment patterns in order to support or substitute a standard employment, is an important factor of active and efficient strategies for society in transitional period.

Flexible part-time models in Ukraine, as well as in a large part of countries with transition economy have a number of features. Administrative leaves are a result of a reduction in labor demand. As shown in Figure 8, the proportion of employees in this mode in Ukraine amounted to $1.3 \%$ in 2012 , but this indicator is higher than pre-crisis one 
$1.1 \%$ in 2007. An important trend in the use of social and employment potential in Ukraine in 1990 s was a rise (from $5.6 \%$ in 1995 to $17.6 \%$ in 1999 ), and in the 2000s - reduction (from $13.3 \%$ in 2000 to $4.4 \%$ in 2007) of the proportion of parttime employees. It should be noted that the result of the financial crisis in the late 2000s was the increase in the level of underemployment in Ukraine to $19.4 \%$ in 2009 , decrease in the level of underemployment in Ukraine in 2012 to $7 \%$ indicates a revival of economic processes in the country.

The deregulation of the market is due to diminution of the importance of the Labor code of Ukraine in favor of individual labor agreements and sectoral collective agreements in favor of agreements in the company. The contract system of employment, the use of part-time working week (day) or temporary work, reduction of the total amount of workers' rights leads to the deregulation too.

For successful restructuring of the implementation of radical transformation and innovative development the flexibility of labor relations is needed. It is necessary to take appropriate actions, which related to all its components - wages, social security forms, working hours etc. One way to perform mentioned tasks is the concept and policy of flexicurity aimed at optimal combination of labor market flexibility and social security resulting in a flexible security model.

Thus, the non-standard forms of employment significantly extend person opportunities when selecting a suitable job and allow more efficient use of the social and employment potential, meet own needs, including material ones. In general, the development of non-standard forms of employment is a step towards the more flexible labor market that is an objective trend all over the world and in Ukraine in particular. Diversification of labor relations is something as inevitable as the modern technological and social and economic transformations objective are.

The increased competition, expansion of globalization processes and the associated labor resources mobility necessitated the formation of the labor market, which would be the most mobile and adequate according to changing conditions of personnel policy. Simplification of hiring and firing procedures, rapid change in quantity and quality of personnel, optimization of the search of staff of the qualifications needed at this point are capable to help companies to remain competitive in the market under crisis conditions. In the last five - six years all labor market actors recognized the need for introducing fundamental changes in the normative-legal field of the employment policy.

The main goal of the state social policy is to maintain employment stability and to prevent serious deterioration of the material conditions of employees in connection with the transformation of the labor market. In addition to the social importance maintaining stability of employment has a significant economic effect, which is particularly important in an era of innovation economy - the need to maintain long-term employment relationships may induce employers to invest considerable funds in education and training of their employees.

But there is a reverse of the coin. Significant costs (associated with the loss of both time and financial investments) that companies have to bear if there is a need for serious structural changes may become an obstacle towards the modernization of both the companies and the economy as a whole. Thus, maintaining the stability of the employment relationships may contribute to preservation of inefficient economic structure of the country. In addition, incentives to a significant influx of new (including foreign) investment disappear, which is due to uncertainty of entrepreneurs about the possibility of rapid modernization of the business, as appropriate. The negative consequences of such a situation may also include: expansion of the proliferation of "gray" business, the increase in stagnant unemployment and increased segmentation of the labor market.

In order not to allow structural changes lead to a significant deterioration of the employees, on the one hand, and become an obstacle to the flow of investments into the economy of the country - on the other hand, the state must maintain a significant impact on the labor market, and its policy should be well-targeted and aimed at modeling of a healthy, educated and skilled workforce that can adapt to changes. 


\section{CONCLUSIONS}

Thus, the non-standard forms of employment significantly extend persons' possibilities when selecting a suitable job and allow more efficient use of its labor potential, meet their needs, including material ones. However, the main disadvantage of employment deformalization is the problem of filling funds for social purposes, shortfall in state budget tax revenues, narrowing budget capacity to fund social infrastructure, social services and social security.

Thus, the advantages and disadvantages of nonstandard employment due to the fact that on the one hand, it is a factor that provides the flexibility of the labor market, but on the other - makes weaker position of workers in this market. Therefore, on the one hand increase the social costs arising from non-standard employment, on the other hand, it is an instrument of adaptation for firms and workers to the changes taking place in the conditions of post-industrial development.

In general, the development of non-standard forms of employment is a step towards more flexible labor market that is an objective trend all over the world and in Ukraine in particular. It is proved that the main factors affecting the formation of non-standard employment is a structural shift in the economy that are dictated by the transition from industrial to post-industrial mass production, significant expansion of services, large-scale implementation of information and communication technologies, in all sectors, strengthening the role of globalization and increasing the flexibility of employment.

\section{WORKS CITED}

Blau, F. \& Kahn L. (2006). The U.S. Gender Pay Gap in the 1990s: Slowing Convergence, Industrial and Labor Relations Review, 60(1), 45-66.

Brainerd E. (2000) Wage Differentials in Eastern Europe and the Former Soviet Union. Industrial and Labor Relations Review, 54(1)

Casey B. (1991) Survey evidence on trends in 'non-standard' employment. In Farewell to Flexibility?. A. Pollert (Ed). Oxford: Blackwell, pp. 179 - 199.

Eurostat (2013), Online Employment and unemployment (LFS) Database: http://epp.eurostat.ec.europa.eu/portal/page/portal/employment_unemployment_lfs/data/database

Houseman S. (2001). Why Employers Use Flexible Staffing Arrangements: Evidence from an Establishment Survey, Indusrial and Labour Relations Review. Vo. I 55. October. № 1. P.161.

Jurajda, Š. (2005). Gender Segregation and Wage Gap: An East-West Comparison”, Journal of the European Economic Association, 3(2-3): 598-607.

Kalleberg A. (2000). Nonstandard Employment Relations:Part-time?, Temporary and Contract Work. P. 342

Labor market analysis(2010). Information technologies. Website. Retrieved from www.rabota.ua

Motorna I. (2008). Conceptual approaches to regulation of social-labor relations under the distant employment conditions, Bulletin of socio-economic research, № 32., P. 283-287.

Newell, A., Reilly, B. (2001). The Gender Pay Gap in the Transition from Communism: Some Empirical Evidence. IZA DP, March, 268

Pastore F, \& Vereshagina A. (2007) When Does Transition Increase the Gender Wage Gap? An Application to Belarus., Moscow: EERC

Pavuk O. \& Moldenhower N. (2013). Employment as an indicator of virtualization economy (for example, U.S.), The Economic Annalis XXI, №11-12(1)',C. 26

Petrova I., Blyzniuk V. \& Kulikov G. (2009). Ukrainian labor market: development characteristics and operating effectiveness , I. Petrova (Ed). NAS of Ukraine; In-t for economics and forecasting. $368 \mathrm{p}$.

State Statistic Service of Ukraine (2013), Economic Activity of Population in Ukraine 2012, Kyiv.

Wilthagen Ton \& Tros Frank (2004) The concept of 'flexicurity': a new approach to regulating employment and labour markets. Transfer, vol. 10, nr.2, p.166-186.

Received for publication: $\quad 10.06 .2014$

Revision received: $\quad 11.09 .2014$

Accepted for publication: $\quad 25.09 .2014$ 


\section{How to cite this article?}

Style - APA Sixth Edition:

Blyzniuk, V., \& Guk, L. (2015, Jan 15). Transformation of institution of employment as an adaptation of the labor market. (Z. Čekerevac, Ed.) MEST Journal, 3(1), 68-80. doi:10.12709/mest.03.03.01.08

Style - Chicago Fifteenth Edition:

Blyzniuk, Victoriia, and Larisa Guk. 2015. "Transformation of institution of employment as an adaptation of the labor market." Edited by Zoran Čekerevac. MEST Journal (MESTE) 3 (1): 68-80. doi:10.12709/mest.03.03.01.08.

Style - GOST Name Sort:

Blyzniuk Victoriia and Guk Larisa Transformation of institution of employment as an adaptation of the labor market [Journal] // MEST Journal / ed. Čekerevac Zoran. - Belgrade : MESTE, Jan 15, 2015. - 1 : Vol. 3. - pp. 68-80.

Style - Harvard Anglia:

Blyzniuk, V. \& Guk, L., 2015. Transformation of institution of employment as an adaptation of the labor market. MEST Journal, 15 Jan, 3(1), pp. 68-80.

Style - ISO 690 Numerical Reference:

Transformation of institution of employment as an adaptation of the labor market. Blyzniuk, Victoriia and Guk, Larisa. [ed.] Zoran Čekerevac. 1, Belgrade : MESTE, Jan 15, 2015, MEST Journal, Vol. 3 , pp. 68-80. 